\title{
Spatial and temporal variation in elemental signatures of statoliths from the Patagonian longfin squid (Loligo gahi)
}

\author{
Alexander I. Arkhipkin, Steven E. Campana, J ennifer FitzGerald, and \\ Simon R. Thorrold
}

\begin{abstract}
We quantified elemental signatures in statoliths of 718 Patagonian longfin squid (Loligo gahi) collected in the vicinity of the Falkland Islands (southwest Atlantic) and at sites on the Patagonian Shelf and coastal Peru. All squid were assigned to a spawning cohort by size, spawning condition, and back-calculated spawning date based on daily increments in statoliths. The remaining statolith was then analyzed for six elemental ratios $(\mathrm{Mg} / \mathrm{Ca}, \mathrm{Mn} / \mathrm{Ca}$, $\mathrm{Sr} / \mathrm{Ca}, \mathrm{Cd} / \mathrm{Ca}, \mathrm{Ba} / \mathrm{Ca}$, and $\mathrm{Pb} / \mathrm{Ca}$ ) using high-resolution inductively coupled plasma mass spectrometry (ICP-MS). Elemental concentrations in the statoliths were broadly similar to other biogenic aragonites. Differences in $\mathrm{Sr} / \mathrm{Ca} \mathrm{ratios}$ in statoliths among geographic locations were generally consistent with a negative correlation between $\mathrm{Sr} / \mathrm{Ca}$ and temperature. Variations in statolith $\mathrm{Cd} / \mathrm{Ca}$ and $\mathrm{Ba} / \mathrm{Ca}$ values confirmed that during winter months, the squid were foraging deeper in the water column. Both $\mathrm{Mg} / \mathrm{Ca}$ and $\mathrm{Mn} / \mathrm{Ca}$ ratios in statoliths decreased with squid size, probably corresponding to a decrease in the contribution of the organic component of the statolith. Elemental signatures in the statoliths of $L$. gahi varied significantly geographically and between spring- and autumn-spawned cohorts, which must therefore have spent significant portions of their life histories in different environments.
\end{abstract}

Résumé : Nous avons quantifié les signatures d'éléments dans les statolithes de 718 calmars patagons (Loligo gahi)
récoltés dans les environs des îles Falkland (Atlantique sud) et à certains sites sur la plate-forme patagonienne et la
côte du Pérou. Tous les calmars ont été assignés à une cohorte de fraye d'après leur taille, leur état reproductif et leur
date de fraye déterminée par rétrocalcul à partir des couches de croissance journalière sur les statolithes. Nous avons
déterminé six rapports d'éléments dans le second statolithe, soit $\mathrm{Mg} / \mathrm{Ca}, \mathrm{Mn} / \mathrm{Ca}, \mathrm{Sr} / \mathrm{Ca}, \mathrm{Cd} / \mathrm{Ca}, \mathrm{Ba} / \mathrm{Ca}$ et $\mathrm{Pb} / \mathrm{Ca}$, après
une analyse par spectrométrie de masse à source de plasma à couplage inductif (ICP-MS) de haute résolution. Les
concentrations d'éléments dans les statolithes sont grossièrement semblables à celles des autres aragonites d'origine
biologique. Les différences de $\mathrm{Sr} / \mathrm{Ca}$ dans les statolithes provenant des diverses localités géographiques s'accordent en
général avec la corrélation négative qui existe entre $\mathrm{Sr} / \mathrm{Ca}$ et la température. Les variations de $\mathrm{Cd} / \mathrm{Ca}$ et de Ba/Ca dans
les statolithes confirment que durant les mois d'hiver les calmars recherchent leur nourriture à de plus grandes profon-
deurs dans la colonne d'eau. Les rapports $\mathrm{Mg} / \mathrm{Ca}$ et $\mathrm{Mn} / \mathrm{Ca}$ déclinent tous les deux à mesure que le calmar grandit, ce
qui correspond probablement à une diminution de la contribution de la composante organique du statolithe. Les signa-
tures des éléments des statolithes de $L$. gahi varient de façon significative en fonction du site géographique, ainsi
qu'entre les cohortes pondues au printemps et à l'automne, qui doivent alors avoir passé une partie significative de leur
temps dans des environnements différents. [Traduit par la Rédaction]

\section{Introduction}

Natural geochemical signatures based on the elemental and isotopic composition of calcified structures are becoming increasingly popular as a tool for investigating population structure and connectivity in marine systems (Thorrold et al. 2002). Although more commonly applied to fish otoliths (reviewed by Campana 1999), many marine inverte- brates also have calcified structures that may be similarly useful as natural tags (Zacherl et al. 2003a). For instance, the statocysts of cephalopod molluscs, including squids, contain statoliths that share many structural similarities with fish otoliths (Clarke 1978). Squid statoliths are composed primarily of aragonite crystals associated with an organic matrix (Radtke 1983). Alternating layers of protein-rich and organic-poor material are deposited on a daily basis in squid

Received 3 July 2003. Accepted 23 February 2004. Published on the NRC Research Press Web site at http://cjfas.nrc.ca on 9 September 2004.

J17588

A.I. Arkhipkin. ${ }^{1}$ Falkland Islands Government Fisheries Department, P.O. Box 598, Stanley, Falkland Islands.

S.E. Campana. Marine Fish Division, Bedford Institute of Oceanography, P.O. Box 1006, Dartmouth, NS B2Y 4A2, Canada.

J. FitzGerald and S.R. Thorrold. Biology Department MS No. 35, Woods Hole Oceanographic Institution, Woods Hole, MA 02543, USA.

${ }^{1}$ Corresponding author (e-mail: aarkhipkin@fisheries.gov.fk). 
statoliths (Jackson 1994). The presence of validated daily increments confirms that material is deposited in statoliths throughout the life of the squid and provides a method for accurate age estimation of individuals. The elemental composition of squid statoliths may therefore represent a useful source of information on habitat use and population structure.

Although the chemistry of squid statoliths has not been used to address population-level questions, biomineralization studies have shown that statoliths contain a number of elements at minor and trace levels (Lipinski 1986; Ikeda et al. 1995). For instance, $\mathrm{Sr}$ has been shown to be essential for normal statolith development (Hanlon et al. 1989). Magnesium may also be a key factor in the calcification process within the statocyst (Morris 1991; Bettencourt and Guerra 2000). Based on an inverse relationship between $\mathrm{Sr} / \mathrm{Ca}$ and temperature in scleractinian corals (Beck et al. 1992), several studies have attempted to use $\mathrm{Sr} / \mathrm{Ca}$ ratios in statoliths as a temperature proxy (Rodhouse et al. 1994; Ikeda et al. 1996, 1999). However, no study to date has shown convincing evidence that $\mathrm{Sr} / \mathrm{Ca}$ ratios in squid statoliths are temperature dependent.

In this study, we investigated the potential of elemental signatures in statoliths as natural markers of cohort and population structure in the Patagonian longfin squid Loligo gahi. The species inhabits relatively cold waters for loliginid squids and is abundant in shelf waters around the Falkland Islands. Loligo gahi undertakes offshore-inshore ontogenetic migrations. After spawning in shallow inshore waters $(20-50 \mathrm{~m}$ depth; Arkhipkin et al. 2000), paralarvae and small juveniles remain on their spawning and nursery grounds (20-100 m depth) until they attain 5-7 cm mantle length, when then move to their offshore deepwater feeding grounds (150$300 \mathrm{~m}$ ). Maturation begins at the end of the feeding period, whereupon the mature squid migrate back inshore to spawn (Hatfield and Des Clers 1998). Two putative cohorts of L. gahi with different spawning times have been identified (Patterson 1988; Carvalho and Pitcher 1989). The autumnspawned cohort spawns inshore in May-June (austral autumn), where the eggs develop for 3-4 months in cold winter conditions. In October-November (austral spring), autumnspawned cohort paralarvae and juveniles stay in inshore waters as the waters warm and then migrate offshore to depths of $100-150 \mathrm{~m}$, where they spend the summer. In autumn (March-May), the autumn-spawned cohort squid move inshore to spawn. The spring-spawned cohort spawns inshore in October and November, where it takes only 1.5-2 months for their eggs to develop in the relatively warm coastal waters. The spring-spawned cohort paralarvae and juveniles stay inshore throughout December-February (austral summer), but in autumn, they start to move offshore to feed. In July-September (austral winter), the autumn-spawned cohort immature squid can be found in the intermediate warm layer at a depth of $200-300 \mathrm{~m}$. They start to mature at the end of winter, and mature spring-spawned cohort squid migrate inshore in September-October to spawn (Arkhipkin et al. 2004). Although squid from the two cohorts may occupy the same habitats, they do so in different seasons; thus, the two cohorts are exposed to different environments in both the spawning and feeding areas. In addition, shelf waters to the southeast of the Falkland Islands are mixed with waters of the cold sub-Antarctic Falkland Current, whereas those to the northwest of the Falkland Islands are mixed with temperate waters originating from the northern part of the Patagonian Shelf (Zyrjanov and Severov 1979). Therefore, squid that spawn and hatch in these two geographical regions of the Falkland Shelf are exposed to very different water masses. Exposure to either different water masses or different environments can often lead to differences in the trace element composition of calcified structures, thus suggesting the possibility of cohort-specific elemental signatures in Falkland Shelf squid.

The objectives of this study were, first, to quantify the elemental composition of Patagonian longfin squid statoliths in Falkland Islands waters and several other locations in the Southern Hemisphere and, second, to provide an initial assessment of elemental signatures characteristic of spawning and feeding aggregations in various locations. We conclude by highlighting the potential applications of statolith elemental signatures for assessing population structure and migration in squid stocks.

\section{Material and methods}

\section{Sample collections}

Loligo gahi were collected during three research cruises onboard the Falkland Islands Fishery Patrol and Research Vessel Dorada during the three austral seasons: spring 1999, summer 2000, and winter 2000. A two-panel bottom trawl (vertical opening $4.5 \mathrm{~m}$, horizontal opening $30 \mathrm{~m}$ ) equipped with a small-mesh liner (40-mm stretched mesh) was used during the surveys. We arbitrarily divided shelf waters into northern and southern locations divided by latitude $52^{\circ} \mathrm{S}$ (Fig. 1), and sampling was conducted at both locations in all seasons. At each location, two different size groups were collected: small immature squid of $<10 \mathrm{~cm}$ mantle length and large mature squid (if present) $>12 \mathrm{~cm}$ mantle length (Fig. 1). It was assumed that mature large squid that had been caught near or during the spawning season belonged to the cohort that spawns during this season, and small immature squid caught around the same date belonged to the cohort that would spawn during the next spawning season. A single sample was taken on the Patagonian Shelf in international waters at $46^{\circ} \mathrm{S}$ in September 2000. Finally, an outgroup sample of large squid from the Pacific coast of Peru was taken from the artisanal fishery near Fronton Island (offshore Callao) in May 2000 and was kindly provided by P. Villegas (Instituto del Mar del Perú, Callao, Peru).

After collection, all squid were measured (mantle length \pm $1 \mathrm{~mm}$ ) and weighed (total body weight $\pm 1 \mathrm{~g}$ ). Sex and maturity stage were identified according to the maturity scale of Lipinski (1979). Then, 50-60 animals of the most abundant size group from a given trawl were selected. The statoliths were dissected from the cartilaginous skull and washed in distilled water. One statolith of each pair was stored in an oil-paper envelope in $96 \%$ ethanol for age studies, and the other statolith was kept dry for chemical analyses.

\section{Statolith processing and reading}

The statoliths sampled for age studies were processed using the age estimation techniques of the Falkland Islands Fisheries Department laboratory (Arkhipkin 1991). Statoliths were mounted to microscopic slides with Permount mount- 
Fig. 1. Sample locations of Loligo gahi in austral spring 1999 $(+)$, summer $2000(\diamond)$, and winter $2000(\triangle)$ in the different regions of the Southwest Atlantic Ocean: southern (S) and northern (N) parts of the Falkland Shelf, northern part (NN) of the Falkland Interim Management and Conservation Zone (FICZ), and Patagonian Shelf at $46^{\circ} \mathrm{S}$ outside the Argentine Exclusive Economic Zone (EEZ) and Falkland Outer Conservation Zone (FOCZ).

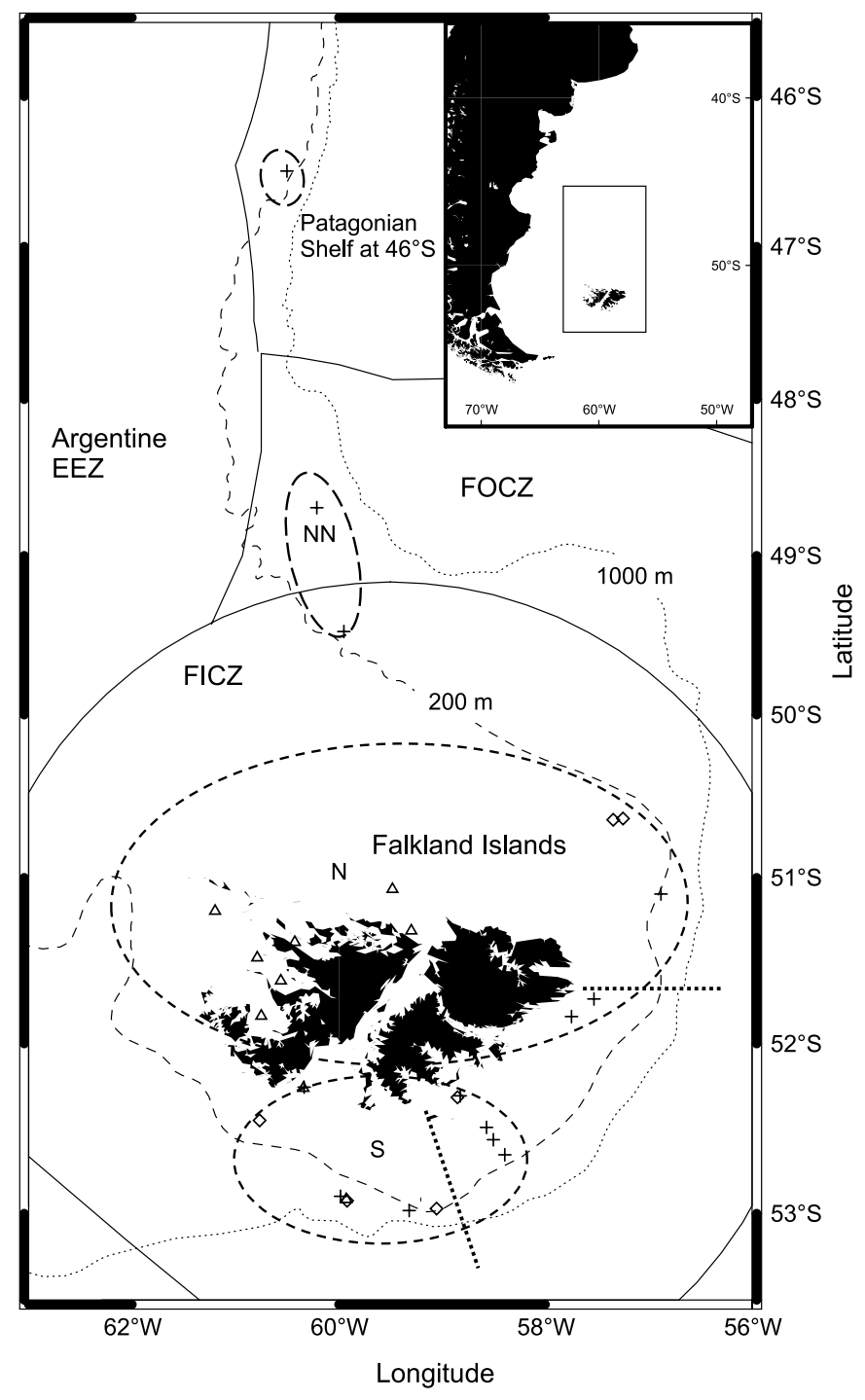

ing medium and ground on both sides with wet waterproof sandpaper (600 grit). Ground statoliths were then embedded in Permount, covered with a cover slip, and then placed in an oven at $50-60{ }^{\circ} \mathrm{C}$ for about $24 \mathrm{~h}$ to dry the Permount and remove any air bubbles. Statoliths were read in the lateral dome near the nucleus and then in the rostrum under an Olympus BX-50 compound microscope (400× magnification) using Nomarski differential interference contrast observation to improve the readability of growth increments. To minimize counting errors, each statolith was counted twice by two observers. The total number of growth increments for each specimen was obtained as a mean of these replicate counts if the deviation between the two counts was $<5 \%$. If the deviation exceeded $5 \%$, the statolith was recounted by
Fig. 2. (a) Near-bottom temperatures in the spawning and nursery grounds $(20-100 \mathrm{~m})$ and feeding grounds $(200 \mathrm{~m})$ in the northern and southern parts of the Falkland Shelf. Northern shelf, 20-100 m = diamonds; southern shelf, 20-100 $\mathrm{m}=$ squares; northern shelf, $200 \mathrm{~m}=$ triangles. (b) Growth of the statolith in weight in juvenile and immature squid Loligo gahi on the Falkland Shelf. $y=0.00008 x^{1.71}, R^{2}=0.62, n=283$.
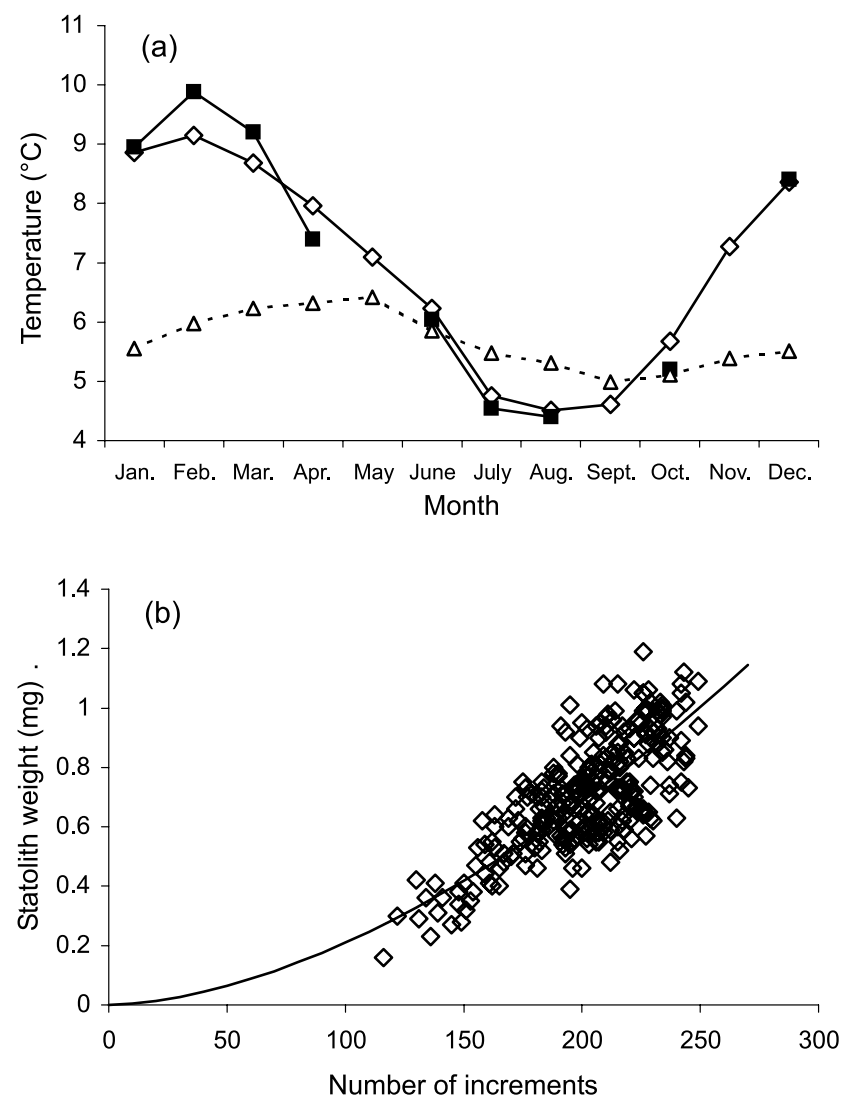

the two observers once more. If the deviation did not decrease after the recounting, the statolith was rejected from further analysis. A total of 796 statoliths were prepared, of which $718(90.2 \%)$ were successfully read.

\section{Age structure analysis}

Daily deposition of statolith growth increments has been validated in a number of loliginid species both in captivity (Jackson 1994) and in the wild (Lipinski et al. 1998). Statolith microstructure in L. gahi was similar to that of other loliginids, so we assumed that the growth increments within L. gahi statoliths were deposited daily and that the total number of increments in a statolith represented the postembryonic age of squid in days. The hatch date distribution was determined for each putative cohort by subtracting the daily age of the squid from the date of collection. Hatch dates were then pooled by month to form monthly cohorts.

\section{Elemental analyses}

The statoliths used for element analysis were initially decontaminated using protocols developed for otoliths outlined in Campana (1999). Briefly, statoliths were cleaned ultrasonically in ultrapure water for $5 \mathrm{~min}$, triple-rinsed in ultrapure 
Fig. 3. Length-frequency distributions of female (left) and male (right) immature (open bars), maturing (shaded bars), and mature (solid bars) Patagonian longfin squid (Loligo gahi) collected in $(a, b)$ October-November 1999, $(c, d)$ February 2000, and $(e, f)$ June 2000 from the Falkland Islands.
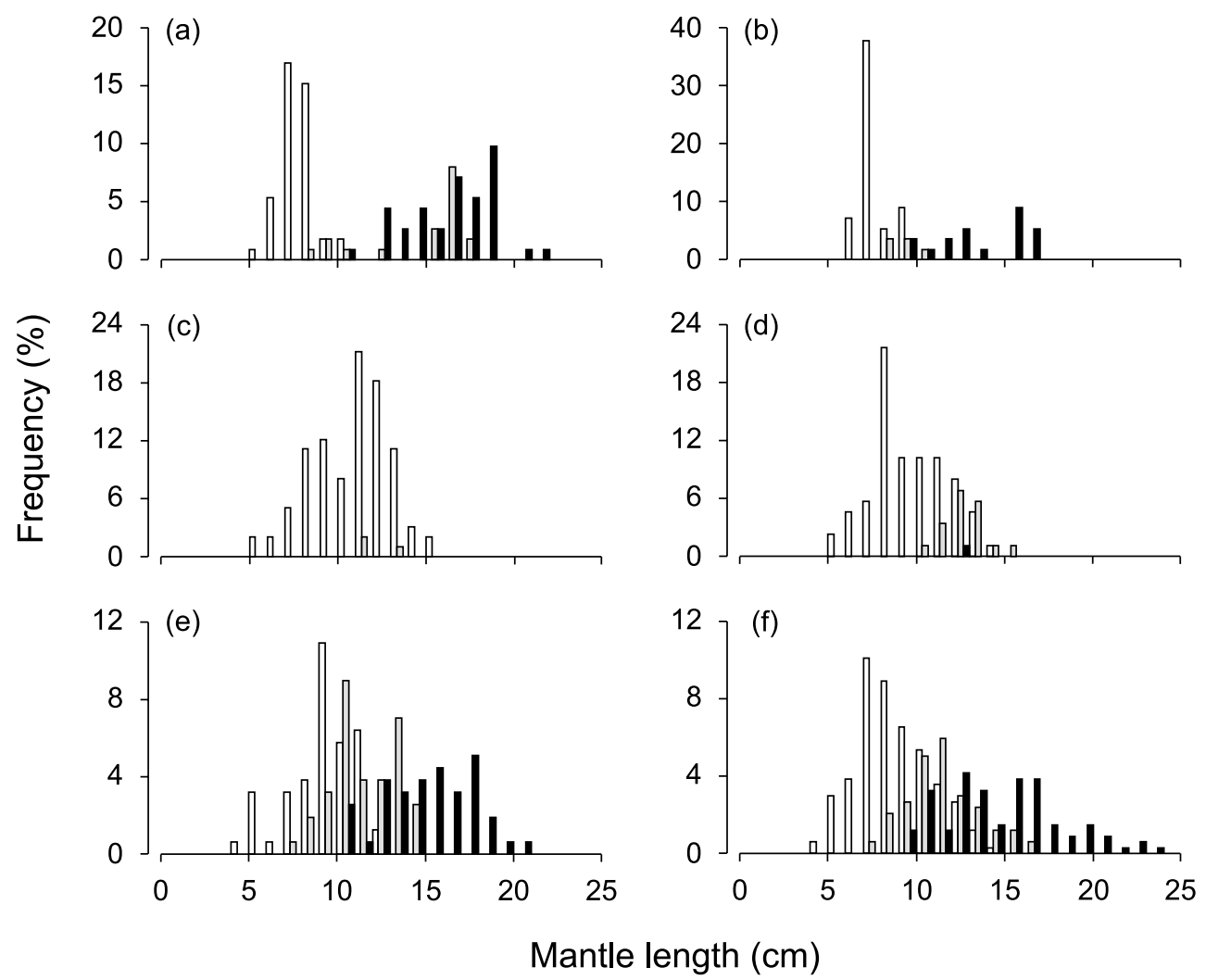

water, and then air-dried under a Class 100 laminar flow hood for 24-36 h. After drying, statoliths were weighed $( \pm 10 \mu \mathrm{g})$ and transferred to acid-washed low-density polyethylene vials for subsequent elemental analysis.

Statoliths were digested in ultrapure $70 \%$ Seastar nitric acid and then diluted to $1 \% \mathrm{HNO}_{3}$ for subsequent analysis by solution-based inductively coupled plasma mass spectrometry (ICP-MS). Dilution of all solutions was standardized to ensure that total $\mathrm{Ca}$ concentrations were identical both among samples and between samples and standards. Samples were analyzed by high-resolution sector field ICPMS on a Finnigan MAT Element2 ICP-MS. We measured a total of seven isotopes in the statoliths $\left({ }^{25} \mathrm{Mg},{ }^{48} \mathrm{Ca},{ }^{55} \mathrm{Mn}\right.$, ${ }^{86} \mathrm{Sr},{ }^{115} \mathrm{Cd},{ }^{138} \mathrm{Ba}$, and $\left.{ }^{208} \mathrm{~Pb}\right)$. Detection limits were calculated as $3 \sigma$ values of $1 \% \mathrm{HNO}_{3}$ sample blanks $(n=83)$ that were run throughout the analyses. These limits were $0.6 \%$ of the average sample intensity for ${ }^{25} \mathrm{Mg}, 0.03 \%$ for ${ }^{48} \mathrm{Ca}, 2.5 \%$ for ${ }^{55} \mathrm{Mn}, 0.03 \%$ for ${ }^{86} \mathrm{Sr}, 5.7 \%$ for ${ }^{114} \mathrm{Cd}, 0.04 \%$ for ${ }^{138} \mathrm{Ba}$, and $6.0 \%$ for ${ }^{208} \mathrm{~Pb}$. Elemental ratios were then quantified by reference to an otolith certified reference material (Yoshinaga et al. 1999, 2000) that was run throughout the session using the method outlined by Rosenthal et al. (1999). We examined precision of the method by treating the otolith certified reference material as an unknown and using an internal laboratory standard to correct for mass bias $(n=28)$. Precision estimates (relative standard deviation) were as follows: $\mathrm{Mg} / \mathrm{Ca}=0.5 \%, \mathrm{Mn} / \mathrm{Ca}=3.6 \%, \mathrm{Sr} / \mathrm{Ca}=0.3 \%, \mathrm{Cd} / \mathrm{Ca}=$ $14.4 \%, \mathrm{Ba} / \mathrm{Ca}=0.6 \%$, and $\mathrm{Pb} / \mathrm{Ca}=1.5 \%$.

\section{Statistical analysis}

We used a combination of univariate and multivariate analyses to examine the spatiotemporal variability in statolith elemental signatures. The squid samples differed in size, location of collection, and cohort. However, we were primarily interested in variability among locations and between cohorts. Therefore, we initially divided the squid into three maturity phases: immature (stages 1 and 2 on the maturity scale by Lipinski 1979), maturing (stages 3 and 4), and mature (stage 5). All comparisons were subsequently made within these three life history phases, with the exception of an examination of ontogenetic trajectories using principal components analysis. To examine the ontogenetic trajectories of the multivariate signatures of Falkland Islands squid, we calculated mean scores and bootstrapped $95 \%$ confidence ellipses on principal components 1 and 2 for each of the three maturity phases and for both spawning cohorts. Canonical discriminant analysis was used to visualize differences in multivariate elemental signatures within maturity stages and between locations and cohorts. Again, bootstrapped 95\% ellipses were calculated on canonical variates 1 and 2 to aid in the interpretation of results from the multivariate ANOVA (MANOVA) (see below).

A more rigorous analysis of elemental signatures, including MANOVA and ANOVA, was conducted on elemental signatures in statoliths from the Falkland Islands locations. All elemental data were initially examined for normality and homogeneity of variance using residual analysis (Winer 
1971), and only $\mathrm{Mg} / \mathrm{Ca}$ ratios required $\log$ transformation to meet these requirements. Two-way MANOVA was then used to determine the fixed effects of cohort and location on statolith elemental composition. Multivariate differences in elemental signatures from the MANOVA were visualized using canonical discriminant analyses. We then used individual two-way ANOVAs to determine those elements contributing significantly to any multivariate differences in the elemental signatures.

\section{Analysis of the relationship between ambient temperature and elemental concentration}

Data on ambient temperatures were collected every month along two transects in the northeastern and southern parts of the Falkland Shelf by the Falkland Islands Fishery Patrol and Research Vessel Dorada in 1999 and 2000 (Fig. 1). A CTDO (conductivity, temperature, depth, and oxygen) sealogger SBE-25 (Sea-Bird Electronics Inc., Bellevue, Washington) was deployed from the surface to 5-10 $\mathrm{m}$ above the bottom to obtain vertical profiles of temperature (degrees Celsius), salinity, and dissolved oxygen (millilitres per litre) at the 20-, 100-, 200-, and 300-m depth contours (Arkhipkin et al. 2004).

Only small immature squid were used $(<7.5 \mathrm{~cm}$ mantle length) in the analysis of the relationship between ambient temperatures and $\mathrm{Sr} / \mathrm{Ca}$ concentrations because they remained in their inshore spawning and nursery grounds where their temperature history (i.e., number of degree-days) could be reconstructed. Larger immature squid $(>7.5 \mathrm{~cm}$ mantle length) migrate to deepwater feeding grounds where the temperatures are different from those inshore (Fig. $2 a$ ), making it difficult to determine an overall temperature history.

Elemental analysis involved the dissolution of the whole statolith, thus integrating the elemental uptake throughout the lifetime of the squid. Since the daily contribution to the overall statolith elemental composition would depend on the daily relative increase in statolith weight, a power curve fit to the statolith weight at age data (Fig. 2b) was used to estimate the daily increases in statolith weight for each age. A temperature history index $(T)$ was then calculated for every small immature squid as follows:

$$
T=\sum_{i=1}^{k} t_{i} m_{i}
$$

where $k$ is the age of squid at capture, $t_{i}$ is the near-bottom temperature (degrees Celsius) experienced by a given squid on the $i$ th day of its life taken from the time series of nearbottom temperature data on the spawning and nursery grounds at depths between 20 and $100 \mathrm{~m}$ (Fig. $2 a$ ), and $m_{i}$ is the proportional daily increase in statolith weight calculated as

$$
m_{i}=\frac{w_{i+1}-w_{i}}{w_{k}}
$$

where $w_{i+1}$ is statolith weight at age $i+1, w_{i}$ is statolith weight at age $i$, and $w_{k}$ is the final statolith weight at squid age at capture $(k)$.
Fig. 4. Hatch-date frequency distributions from (a) springspawned and $(b)$ autumn-spawned cohorts of Patagonian longfin squid (Loligo gahi) collected at sites north (solid bars) and south (open bars) of the Falkland Islands.

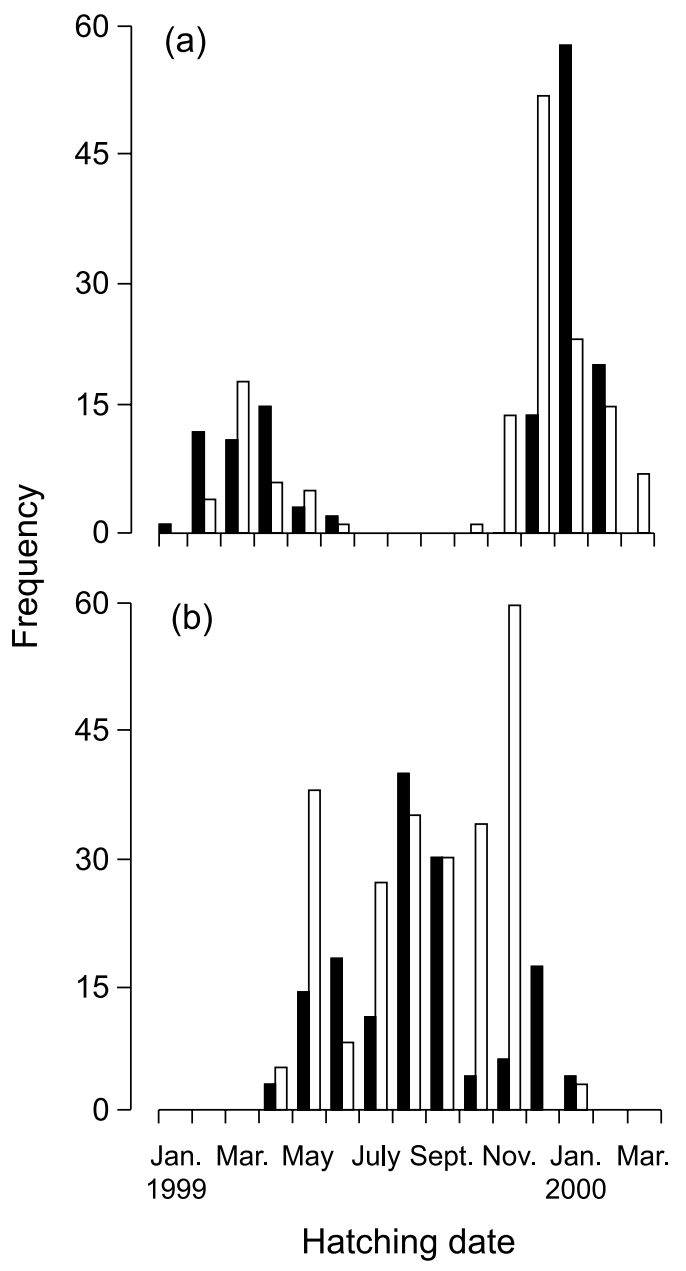

\section{Results}

\section{Length-frequency and age structure analysis}

Two distinct modes were observed in the length-frequency distributions of males and females during October-November 1999 (Fig. 3). Small immature squid of $7 \mathrm{~cm}$ modal mantle length were assumed to have come from the autumnspawned cohort, and large mature squid (15-17 cm modal mantle length) were assigned to the spring-spawned cohort. In February 2000, representing the start of the feeding period for the spring-spawned cohort and its finish for the autumn-spawned cohort, length-frequencies were unimodal for both males and females. Females were almost exclusively immature, whereas in males, the largest squid comprised both immature and mature animals. All squid caught in February were assumed to belong to the autumn-spawned cohort. Collections in June 2000 consisted of several lengthfrequency modes at all maturity stages. Immature squid sampled during this season were assumed to belong to the spring-spawned cohort, whereas mature squid presumably belonged to the autumn-spawned cohort. 
Fig. 5. Mean element/Ca ratios (+2 standard errors) quantified in statoliths of immature (open bars), maturing (shaded bars), and mature (solid bars) Patagonian longfin squid (Loligo gahi) from spring-spawned cohorts collected north (NS) and south (SS) of the Falkland Islands, from autumn-spawned cohorts collected north (NA) and south (SA) of the Falkland Islands, and from maturing and mature individuals from the Patagonian Shelf (PS) and Peru (PE).
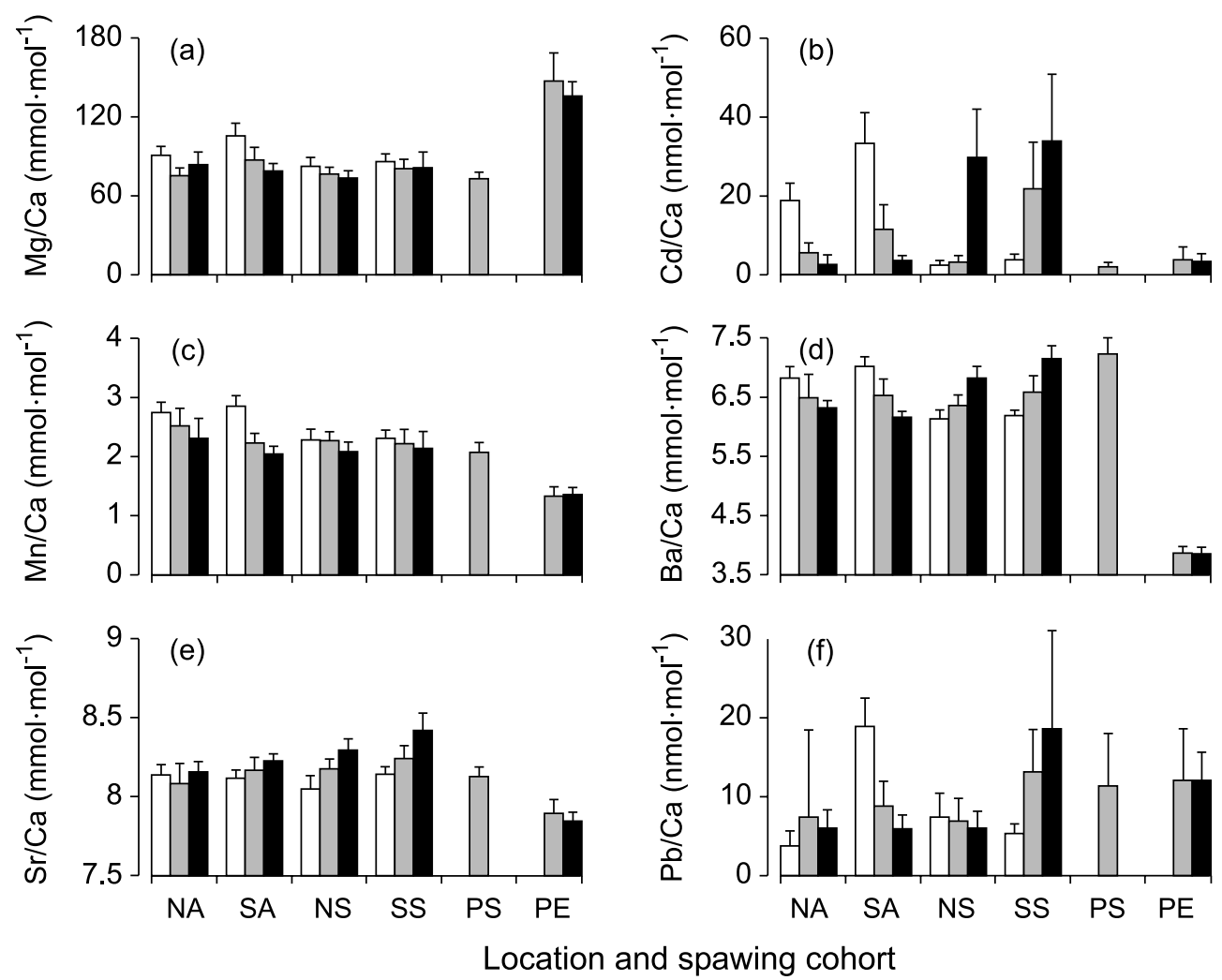

The primary cohort designation by size-class and maturity stage of squid in different seasons was subsequently verified by age estimation using daily increments in statoliths. Backcalculated spawning dates revealed that the squid in our collections hatched throughout the year, without any obvious peaks in reproductive output. There were some inconsistencies in cohort designation between the direct estimates provided by the statolith analyses and the indirect estimates based on mantle length and maturity stage. For instance, approximately 50\% of the squid hatched in December 1999 were mature in June 2000 (and therefore had been assigned to the autumn-spawned cohort), and the remainder were small and immature at the same time and therefore assigned to the spring-spawned cohort (Fig. 4). Similarly, squid that hatched in December 1999 and were mature in June 2000 were assigned to the autumn-spawned cohort for the purposes of the present study. There was, therefore, considerable variability in growth and maturation rates of squid, particularly for those individuals hatched in December. Cohort designations based on direct estimates from daily increments in statoliths were consequently used for all further analyses.

\section{Large-scale geographic variability in elemental signatures}

Elemental concentrations in L. gahi statoliths, expressed as ratios to $\mathrm{Ca}$, ranged over six orders of magnitude (Fig. 5). Strontium values were approximately $8 \mathrm{mmol} \cdot \mathrm{mol}^{-1}$ followed by $\mathrm{Mg} / \mathrm{Ca}\left(70-170 \mu \mathrm{mol} \cdot \mathrm{mol}^{-1}\right), \mathrm{Ba} / \mathrm{Ca}\left(3-8 \mu \mathrm{mol} \cdot \mathrm{mol}^{-1}\right)$, $\mathrm{Mn} / \mathrm{Ca}\left(1-3 \mu \mathrm{mol} \cdot \mathrm{mol}^{-1}\right), \mathrm{Cd} / \mathrm{Ca}\left(2-50 \mathrm{nmol} \cdot \mathrm{mol}^{-1}\right)$, and $\mathrm{Pb} / \mathrm{Ca}\left(2-30 \mathrm{nmol} \cdot \mathrm{mol}^{-1}\right)$. Several elements showed a con- sistent pattern with maturity stage. For instance, $\mathrm{Mg} / \mathrm{Ca}$ and $\mathrm{Mn} / \mathrm{Ca}$ ratios typically decreased from highest values in statoliths from immature squid to lower values in mature individuals. Strontium values showed the opposite pattern and were generally higher in the statoliths of mature stage squid than in either immature or maturing squid. There were also interactions among maturity stages and spawning cohorts. Both $\mathrm{Ba} / \mathrm{Ca}$ and $\mathrm{Cd} / \mathrm{Ca}$ ratios increased with maturity stage in the autumn-spawned cohort but decreased with maturity stage in the spring-spawned cohort (Fig. 5). Lead values showed a similar pattern for the southern Falkland Islands sites, but at the northern site, $\mathrm{Pb} / \mathrm{Ca}$ values were uniformly low across all maturity stages.

We used MANOVA and canonical discriminant analysis to visualize elemental differences among locations in multivariate space (Fig. 6). Elemental signatures of immature squid from the Falkland Islands sites differed significantly (MANOVA, Pillai's trace $=0.61, F=15.4, \mathrm{df}_{\text {numerator }}=18$, $\left.\mathrm{df}_{\text {denominator }}=1086, p<0.05\right)$, with autumn- and summerspawned cohorts separated along canonical variate 1. Maturing squid were collected over a larger geographic area, with samples from Peru and the Patagonian Shelf as well as the Falkland Islands locations. Separation among locations was again significant (MANOVA, Pillai's trace $=1.14, F=$ $\left.9.2, \mathrm{df}_{\text {numerator }}=30, \mathrm{df}_{\text {denominator }}=930, p<0.05\right)$, with the Peruvian squid clearly distinct from Patagonian Shelf and Falkland Islands squid along canonical variate 1. Statoliths from the Peruvian squid were lower in $\mathrm{Mn} / \mathrm{Ca}, \mathrm{Sr} / \mathrm{Ca}$, and $\mathrm{Ba} / \mathrm{Ca}$ and higher in $\mathrm{Mg} / \mathrm{Ca}$ than statoliths from the Atlantic 
Fig. 6. Plot of first two canonical variates contrasting multivariate elemental signatures in statoliths of $(a)$ immature, $(b)$ maturing, and (c) mature Loligo gahi from spring-spawned cohorts collected north $(\square)$ and south $(\bigcirc)$ of the Falkland Islands, from autumn-spawned cohorts collected north $(\boldsymbol{\square})$ and south $(\boldsymbol{O})$ of the Falkland Islands, and from maturing and mature individuals from the Patagonian Shelf $(\bullet)$ and Peru ( $(\mathbf{)})$.
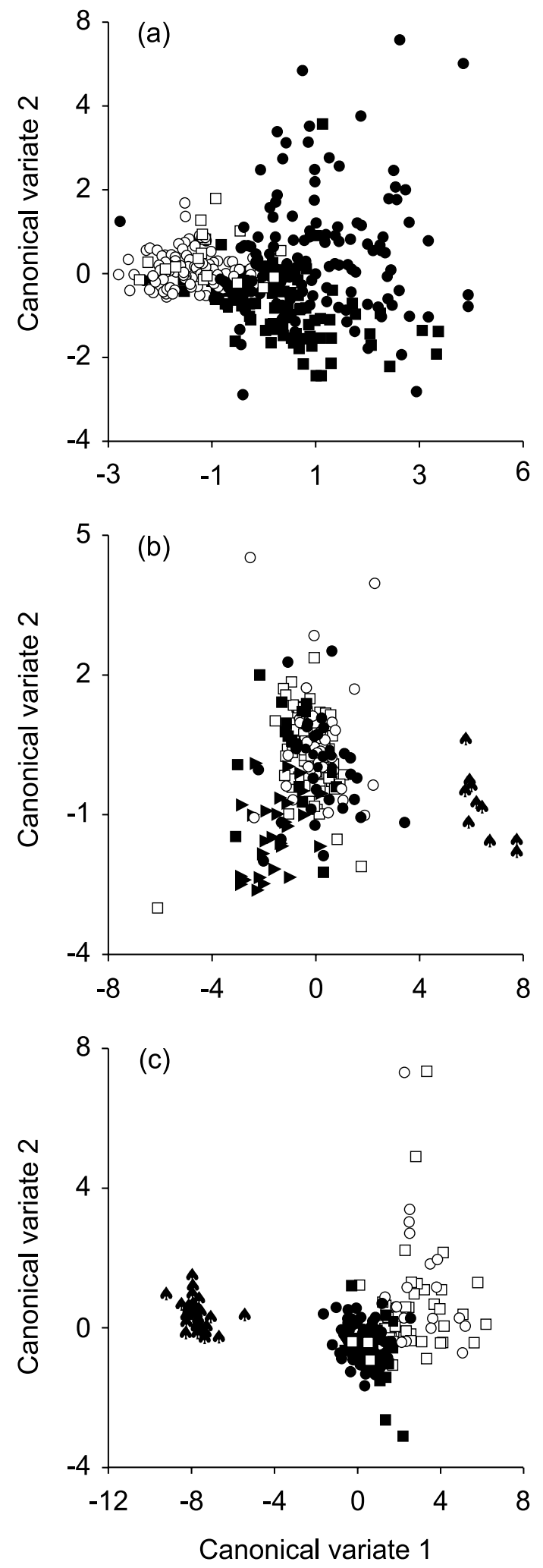

Fig. 7. Plot of elemental loadings and bootstrapped 95\% confidence ellipses around the first two principal components contrasting multivariate elemental signatures in statoliths of immature (I), juvenile (J), and mature (M) Patagonian longfin squid (Loligo gahi) from spring-spawned (open ellipses) and autumn-spawned (shaded ellipses) cohorts.

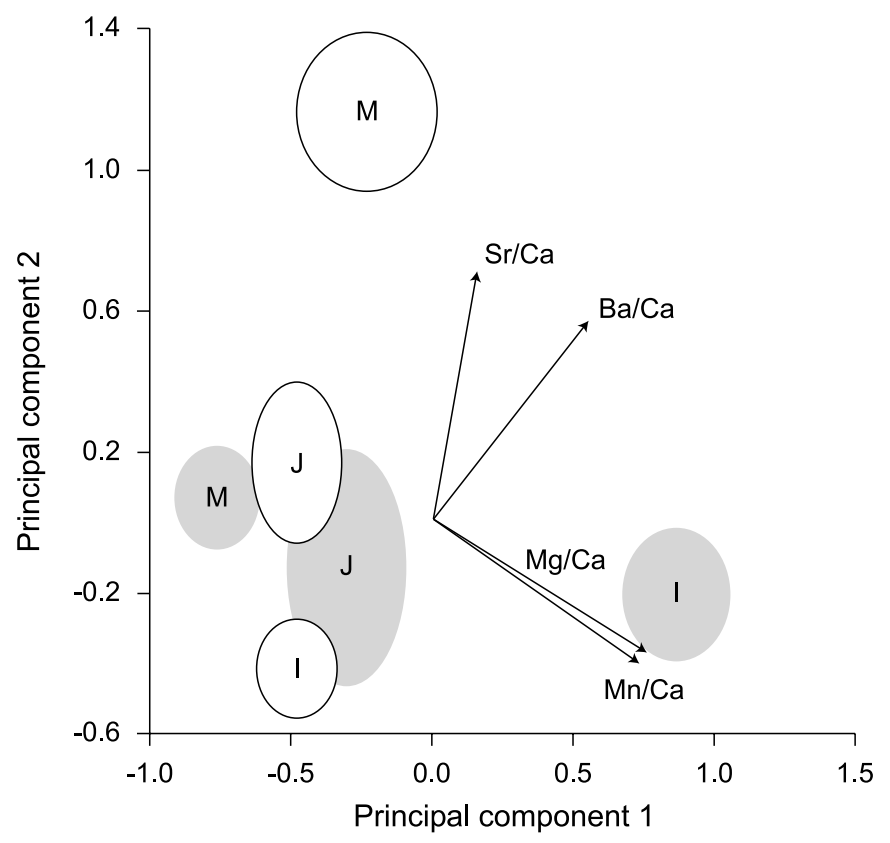

squid (Fig. 5). Elemental signatures from the Patagonian squid were also separated from Falkland Islands sites, although unlike the Peruvian samples, there was a degree of overlap between the two locations. Finally, elemental signatures from mature squid collected from Falkland Islands locations and Peru were differed significantly in multivariate space $\left(\right.$ MANOVA, Pillai's trace $=1.29, F=16.6, \mathrm{df}_{\text {numerator }}=$ $\left.24, \mathrm{df}_{\text {denominator }}=836, p<0.05\right)$. Peru and Falkland Islands locations were completely separated along canonical variate 1 , and there was little overlap between spring and autumn cohorts from the Falkland Islands (Fig. 6).

\section{Spatiotemporal variations in elemental signatures}

To provide a more rigorous test of the ability of elemental signatures in statoliths as location and cohort specific natural tags, we restricted detailed statistical treatment of the elemental signatures to samples from the Falkland Islands locations. We also dropped $\mathrm{Cd} / \mathrm{Ca}$ and $\mathrm{Pb} / \mathrm{Ca}$ from the analyses. Both elements were present in statoliths at ultratrace levels and hence were approaching the detection limits of our instrumentation and susceptible to contamination. The following analyses therefore consisted of squid grouped according to spawning cohort (autumn or spring), geographic location (collected either north or south of $52{ }^{\circ} \mathrm{S}$ ), and maturity phase (immature, maturing, and mature).

We first examined the trajectories of statolith elemental signatures from spring- and autumn-spawned cohorts using principal components analysis (Fig. 7). The first two principal components explained approximately $40 \%$ and $38 \%$ of the variation in the data, respectively. There were clear differences among maturity stages within a cohort and between cohorts. For instance, maturity stages from the autumn- 
Table 1. Results of two-way MANOVA of elemental signatures $(\mathrm{Mg} / \mathrm{Ca}, \mathrm{Mn} / \mathrm{Ca}, \mathrm{Sr} / \mathrm{Ca}$, and $\mathrm{Ba} / \mathrm{Ca}$ ) in statoliths of spring- and autumn-spawned cohorts of Patagonian longfin squid statoliths collected from locations north and south of the Falklands Islands.

\begin{tabular}{lllclll}
\hline Maturity stage & Source & Value & $F$ & $\mathrm{df}_{\text {numerator }}$ & $\mathrm{df}_{\text {denominator }}$ & $p$ \\
\hline Immature & Location & 0.0281 & 2.594 & 4 & 359 & $* * *$ \\
& Cohort & 0.4595 & 76.30 & 4 & 359 & $* * *$ \\
\multirow{3}{*}{ Maturing } & Location $\times$ cohort & 0.0438 & 4.106 & 4 & 359 & $* * *$ \\
& Location & 0.1186 & 4.943 & 4 & 147 & $* * *$ \\
\multirow{3}{*}{ Mature } & Cohort & 0.0634 & 2.487 & 4 & 147 & $* * *$ \\
& Location $\times$ cohort & 0.0434 & 1.669 & 4 & 147 & $\mathrm{~ns}$ \\
& Location & 0.2231 & 12.85 & 4 & 179 & $* * *$ \\
& Cohort & 0.4717 & 39.95 & 4 & 179 & $* * *$ \\
& Location $\times$ cohort & 0.1037 & 5.176 & 4 & 179 & $* * *$ \\
\hline
\end{tabular}

Note: The value is Pillai's trace statistic. ${ }^{* * *}, p$, significant at $\alpha=0.05$; ns, nonsignificant.

spawned cohort separated linearly along principal component 1, while maturity stages from the spring-spawned cohort were similarly separated along principal component 2. Elemental loadings on the principal components of autumnspawned squid showed that $\mathrm{Mg} / \mathrm{Ca}$ and $\mathrm{Mn} / \mathrm{Ca}$ ratios decreased from immature to mature stages. In contrast, differences among maturity stages in the spring-spawned cohort were generated by $\mathrm{Sr} / \mathrm{Ca}$ and $\mathrm{Ba} / \mathrm{Ca}$ values that increased from immature to mature stages.

Multivariate elemental signatures in squid statoliths differed significantly both between spring and autumn-spawned cohorts and between north and south locations across all three maturity phases (Table 1). Elemental signatures of immature squid differed significantly between autumn- and spring-spawned cohorts and between north and south locations. The significant interaction term was interpreted by examining bootstrapped $95 \%$ confidence ellipses on the first two variates from a canonical discriminant analysis of the elemental signatures (Fig. 8). The plot showed that although squid from the autumn-spawned cohort were separated according to location, there was significantly more variability in the statoliths of spring-spawned squid from the northern location compared with those from the southern location. Maturing squid were significantly different between cohorts and locations (Table 1). The interaction term was insignificant. The canonical discriminant analysis plot showed that spawning cohorts were separated along the first canonical variate, and locations were, in turn, separated on the second variate. Finally, location, cohort, and the location $\times$ cohort interaction were all significant in the MANOVA of elemental signatures in mature squid statoliths (Table 1). The significant interaction was generated by the observation that the north and south summer cohort was separated along the first canonical variate only, whereas autumn-spawned squid from the northern location were separated from the other three groupings on the second canonical variate (Fig. 8). The significant interactions were not generated by variations in size within the maturity stages either between cohorts or locations. Two-way ANOVA detected no differences in mantle lengths between locations or cohorts for immature, maturing, or mature maturity stages ( $p>0.05$ for both main effects in all maturity stages).

We used ANOVA to examine the contribution of individual elements to differences in the multivariate signatures be- tween squid cohorts and geographic locations (Table 2; Fig. 5). Univariate differences among immature groups of squid were significant between cohorts for $\mathrm{Mg} / \mathrm{Ca}$ (autumn > spring), $\mathrm{Mn} / \mathrm{Ca}$ (autumn > spring), and $\mathrm{Ba} / \mathrm{Ca}$ (autumn > spring) and between locations for $\mathrm{Mg} / \mathrm{Ca}$ (south > north). Interaction terms were not significant for any of the elements. In contrast, maturing squid were characterized by significant differences between locations for $\mathrm{Mg} / \mathrm{Ca}$ (south > north), $\mathrm{Mn} / \mathrm{Ca}$ (north > south), $\mathrm{Sr} / \mathrm{Ca}$ (south > north), and $\mathrm{Ba} / \mathrm{Ca}$ (south $>$ north) rather than between cohorts where only $\mathrm{Sr} / \mathrm{Ca}$ (spring > autumn) was significant. Again, none of the interaction terms were significant. Both $\mathrm{Sr} / \mathrm{Ca}$ (spring > autumn) and $\mathrm{Ba} / \mathrm{Ca}$ (spring > autumn) ratios were significantly different between cohorts in mature squid, with $\mathrm{Sr} / \mathrm{Ca}$ ratios also showing a significant effect of location (south $>$ north).

\section{Relationship between ambient temperature and elemental concentration}

The ambient temperatures in bottom waters of the inshore spawning and nursery grounds varied seasonally, being maximum at the end of the austral summer $\left(>9{ }^{\circ} \mathrm{C}\right.$ in February) and minimum at the end of winter $\left(<5{ }^{\circ} \mathrm{C}\right.$ in August $)$. Temperature trends in the deeper feeding grounds were different, with the maximum being at the end of autumn $\left(\sim 6^{\circ} \mathrm{C}\right)$ and the minimum being in the beginning of spring $\left(\sim 5^{\circ} \mathrm{C}\right)$. Near-bottom temperatures in shallow waters did not vary significantly between geographical regions (north and south) at any given time of the year (Fig. 2a), and therefore, all small immature squid $(<7.5 \mathrm{~cm}$ mantle length, mean $6.3 \mathrm{~cm}$ mantle length) sampled in both regions were pooled to analyze the possible temperature effect on $\mathrm{Sr} / \mathrm{Ca}$ concentrations in their statoliths.

Temperature history indices in small squid varied from 5.4 to 9.3 (Fig. 9). There was a significant linear regression with a negative slope between $\mathrm{Sr} / \mathrm{Ca}$ concentration and the temperature history index data $(F=41.53, p<0.0001)$, indicating that squid that grew up in the coldest water had the highest Sr/Ca concentration (Fig. 9a). A similar analysis for $\mathrm{Ba} / \mathrm{Ca}$ also showed a significant negative slope $(F=36.82$, $P<0.0001$ ) (Fig. 9b), while the relationships for $\mathrm{Mg} / \mathrm{Ca}$ and $\mathrm{Mn} / \mathrm{Ca}$ with the temperature index were both significantly positive $(F=32.02$ and $F=18.14$, respectively, $p<0.0001)$ (Figs. $9 c$ and $9 d$ ). In all cases, the amount of variance explained by the regressions was small. 


\section{Discussion}

Squid statoliths share many geochemical and microstructural properties with the otoliths of teleost fishes. Both structures are composed primarily of calcium carbonate and are formed of alternating layers of protein and aragonite that are deposited on a daily basis (Jackson 1994). The chemistry of fish otoliths has been used extensively to reconstruct environmental histories of individuals and as natural tags of stock structure (Campana 1999). In contrast, there have only been a handful of studies examining the chemical composition of squid statoliths. Our results are difficult to compare directly with those of previous workers because the earlier work was conducted with probe-based instrumentation focused on small parts of the statolith, unlike the ICP-MS analysis of whole statoliths used in the present study. However, all studies have found that, similar to corals and sclerosponges, statoliths are composed of aragonite containing more $\mathrm{Sr}\left(\sim 8 \mathrm{mmol} \cdot \mathrm{mol}^{-1}\right.$; this study) than fish otoliths or mollusc shells $\left(\sim 2 \mathrm{mmol} \cdot \mathrm{mol}^{-1}\right.$; Campana and Thorrold 2001). Among cephalopods, statolith $\mathrm{Sr} / \mathrm{Ca}$ ratios in $L$. gahi were relatively low compared with those of the nektonic ommastrephid squid Todarodes pacificus $\left(8.5-10 \mathrm{mmol} \cdot \mathrm{mol}^{-1}\right.$; Ikeda et al. 1997) and with a species of benthic octopus, Octopus dofleini (10.6-14.3 mmol-mol ${ }^{-1}$; Ikeda et al. 1999). However, our statolith $\mathrm{Sr} / \mathrm{Ca}$ data were similar to those of several other loliginid squid species reported by Ikeda et al. (1997). We also found that $\mathrm{Mn} / \mathrm{Ca}$ values were almost an order of magnitude lower $\left(1.3-2.9 \mu \mathrm{mol} \cdot \mathrm{mol}^{-1}\right)$ in L. gahi statoliths than in T. pacificus (22-35 $\left.\mu \mathrm{mol} \cdot \mathrm{mol}^{-1}\right)$ and $O$. dofleini (22$\left.40 \mu \mathrm{mol} \cdot \mathrm{mol}^{-1}\right)$ determined by proton-induced X-ray emission (Ikeda et al. 1995, 1999). It seems unlikely that these differences reflect environmental variability in dissolved $\mathrm{Mn}$ concentrations, given the distribution of $\mathrm{Mn}$ in the world's oceans (Donat and Bruland 1995). Rather, we suspect that these differences are either due to taxon-specific differences in elemental uptake or perhaps to an instrumental artefact.

The demonstration by Beck et al. (1992) that Sr distribution coefficients in coral aragonite were temperature dependent has led to a number of studies using $\mathrm{Sr} / \mathrm{Ca}$ thermometry to reconstruct water temperatures in ancient and modern ocean waters (e.g., Swart et al. 2002). In contrast, attempts to establish a correlation between $\mathrm{Sr} / \mathrm{Ca}$ ratio and temperature in squid statoliths have generally failed to produce any supportive data (e.g., Ikeda et al. 1997, 2002; Yatsu et al. 1998). Temperate oceanic ommastrephid squid species such as Ommastrephes bartrami had a much higher $\mathrm{Sr}$ content in their statoliths than did subtropical Dosidicus gigas and tropical Sthenoteuthis oualaniensis (Ikeda et al. 1997), yet an inverse relationship between ambient temperature and $\mathrm{Sr} / \mathrm{Ca}$ ratio would be expected if temperature effects on $\mathrm{Sr}$ uptake were similar to that of gastropod statoliths (Zacherl et al. $2003 b$ ). Strontium concentration in the juvenile phase of $O$. bartrami (near the statolith nucleus) was also higher than in its immature adult phase (near the midpoint of the statolith); the current hypothesis that $O$. bartrami is spawned and its juveniles occur in warmer waters than do the adult squid (Yatsu et al. 1998) would suggest a reversed $\mathrm{Sr} / \mathrm{Ca}$ relationship. Finally, $\mathrm{Sr} / \mathrm{Ca}$ ratios were not significantly different in D. gigas caught in El Niño and La Niña years in Peruvian waters (Ikeda et al. 2002), despite the difference in
Fig. 8. Bootstrapped $95 \%$ confidence ellipses around the first two canonical variates contrasting multivariate elemental signatures in statoliths of $(a)$ immature, $(b)$ maturing, and $(c)$ mature Patagonian longfin squid (Loligo gahi) from spring-spawned cohorts collected north (NS) and south (SS) of the Falkland Islands and from autumn-spawned cohorts collected north (NA) and south (SA) of the Falkland Islands.
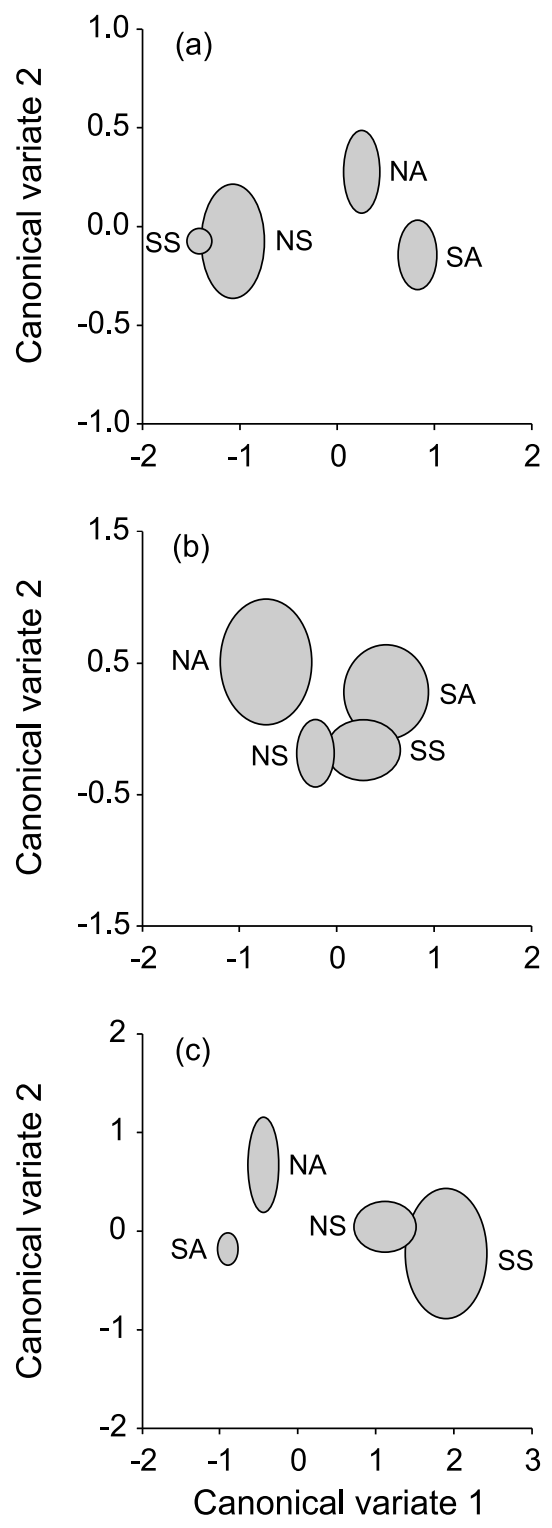

water temperatures. It seems possible, however, that the failure to find a correspondence between ambient temperature and $\mathrm{Sr} / \mathrm{Ca}$ ratio in statoliths is due to the extensive diel vertical migrations of oceanic ommastrephids. During the day, they rest at great depths $(400-800 \mathrm{~m})$ and low temperatures, ascending at night to the warmer surface layers to feed (Yatsu et al. 1998; Nigmatullin et al. 2001). With such a range of temperatures occupied during the day, it is difficult to estimate an integrated temperature history with which to compare observed statolith $\mathrm{Sr} / \mathrm{Ca}$ values.

Loliginid squid occur mainly in the near-bottom layers on the shelf, and their vertical migrations are not as extensive as those of ommastrephids (Hanlon and Messenger 1996). There- 
Fig. 9. Relationships between temperature history index and elemental concentrations of (a) $\mathrm{Sr} / \mathrm{Ca},(b) \mathrm{Ba} / \mathrm{Ca},(c) \mathrm{Mg} / \mathrm{Ca}$, and $(d) \mathrm{Mn} / \mathrm{Ca}$ in statoliths of small immature squid Loligo gahi on the Falkland Shelf.
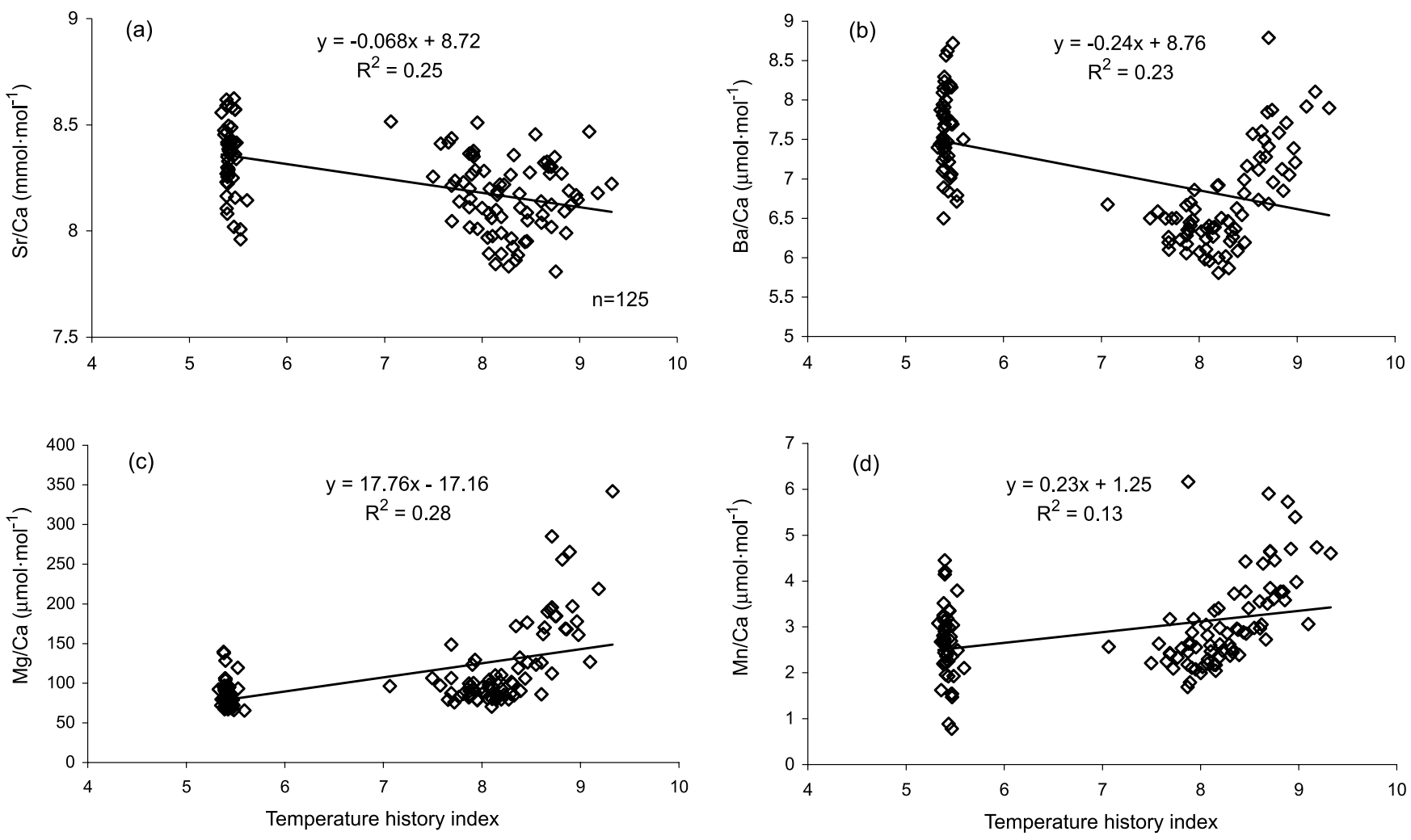

fore, at each ontogenetic phase, loliginids occur at a much narrower (and more easily estimated) temperature range than ommastrephids. For example, $\mathrm{Sr} / \mathrm{Ca}$ concentration in temperate Loligo bleekeri from Japanese waters was significantly higher than those of tropical Loligo duvauceli, Loligo chinensis, and Loligo edulis from the Andaman Sea and Gulf of Thailand (Ikeda et al. 1997).

Our data provided some circumstantial evidence for a negative correlation between temperature and statolith $\mathrm{Sr} / \mathrm{Ca}$ in L. gahi. Squid from Peruvian waters inhabiting waters at 11-12 ${ }^{\circ} \mathrm{C}$ had significantly lower statolith $\mathrm{Sr} / \mathrm{Ca}$ ratios than their South Atlantic counterparts living at 4.5-9 ${ }^{\circ} \mathrm{C}$ (Arkhipkin et al. 2004). Moreover, small immature L. gahi from the Falkland Islands waters growing up in winter temperatures had significantly higher $\mathrm{Sr} / \mathrm{Ca}$ concentrations than juveniles growing up in warmer summer waters. Strontium levels were also significantly higher in maturing and mature squid from sites south of the Falkland Islands than in those from sites north of the islands, which presumably was consistent with lower ambient temperatures experienced by the squid from more southern waters. Thus, it is possible that the $\mathrm{Sr} / \mathrm{Ca}$ ratio in the statolith is an indicator of ambient water temperature at different ontogenetic phases of both cohorts of L. gahi. Clearly, experimental studies are required to ascertain the temperature dependence of $\mathrm{Sr} / \mathrm{Ca}$ ratios in the statoliths of L. gahi and other loliginid squids.

Cadmium and $\mathrm{Ba}$ in statoliths showed very similar patterns of variation between cohorts and locations and among maturity stages. Highest $\mathrm{Cd} / \mathrm{Ca}$ and $\mathrm{Ba} / \mathrm{Ca}$ values were found in immature squids from the autumn-spawned cohorts and mature squid from the spring-spawned cohort. Interest-

ingly, squid from these specific cohorts and maturity stages were collected primarily in the winter of 2000. Both Ba and $\mathrm{Cd}$ have nutrient-type distributions in the ocean waters whereby concentrations of both elements typically increase with depth (Boyle 1988; Lea et al. 1989). Intensification of upwelling in shelf waters around the Falkland Islands during winter months may therefore explain the elevated levels of $\mathrm{Cd}$ and $\mathrm{Ba}$ in the statoliths of immature and mature squid collected in June 2000. Alternatively, these squid may have migrated into deeper water during the winter. Arkhipkin et al. (2004) noted that L. gahi were indeed concentrated in a warmwater layer between 150 and $250 \mathrm{~m}$ during winter months in shelf waters adjacent to the Falkland Islands. Lead values from statoliths were correlated with $\mathrm{Cd} / \mathrm{Ca}$ and $\mathrm{Ba} / \mathrm{Ca}$ at southern locations, showing a decrease with age in the autumn spawning but not at northern locations where both cohorts and all maturity stages had low and constant $\mathrm{Pb} / \mathrm{Ca}$ levels. Lead is a scavenged element with a short oceanic residence time, and therefore, $\mathrm{Pb}$ concentrations decrease with source distance and with depth (Donat and Bruland 1995). This, in turn, suggests that dissolved $\mathrm{Pb}$ is likely influenced by advective rather than upwelling features in shelf waters of the Falkland Islands.

We found similar ontogenetic patterns in the $\mathrm{Mg} / \mathrm{Ca}$ and $\mathrm{Mn} / \mathrm{Ca}$ ratios of squid statoliths. Immature squid statoliths were characterized by relatively high values for both elements that then declined progressively from maturing to mature individuals. Magnesium has been assumed to be important for Ca biomineralization in squid statoliths (Morris 1991). Recently, Bettencourt and Guerra (2000) found that $\mathrm{Mg}^{2+}$ concentration in the statocyst endolymph is negatively corre- 
Table 2. Results of two-way ANOVA of element/Ca ratios quantified in statoliths of Patagonian longfin squid from spring- and autumn-spawned cohorts collected at locations north and south of the Falkland Islands.

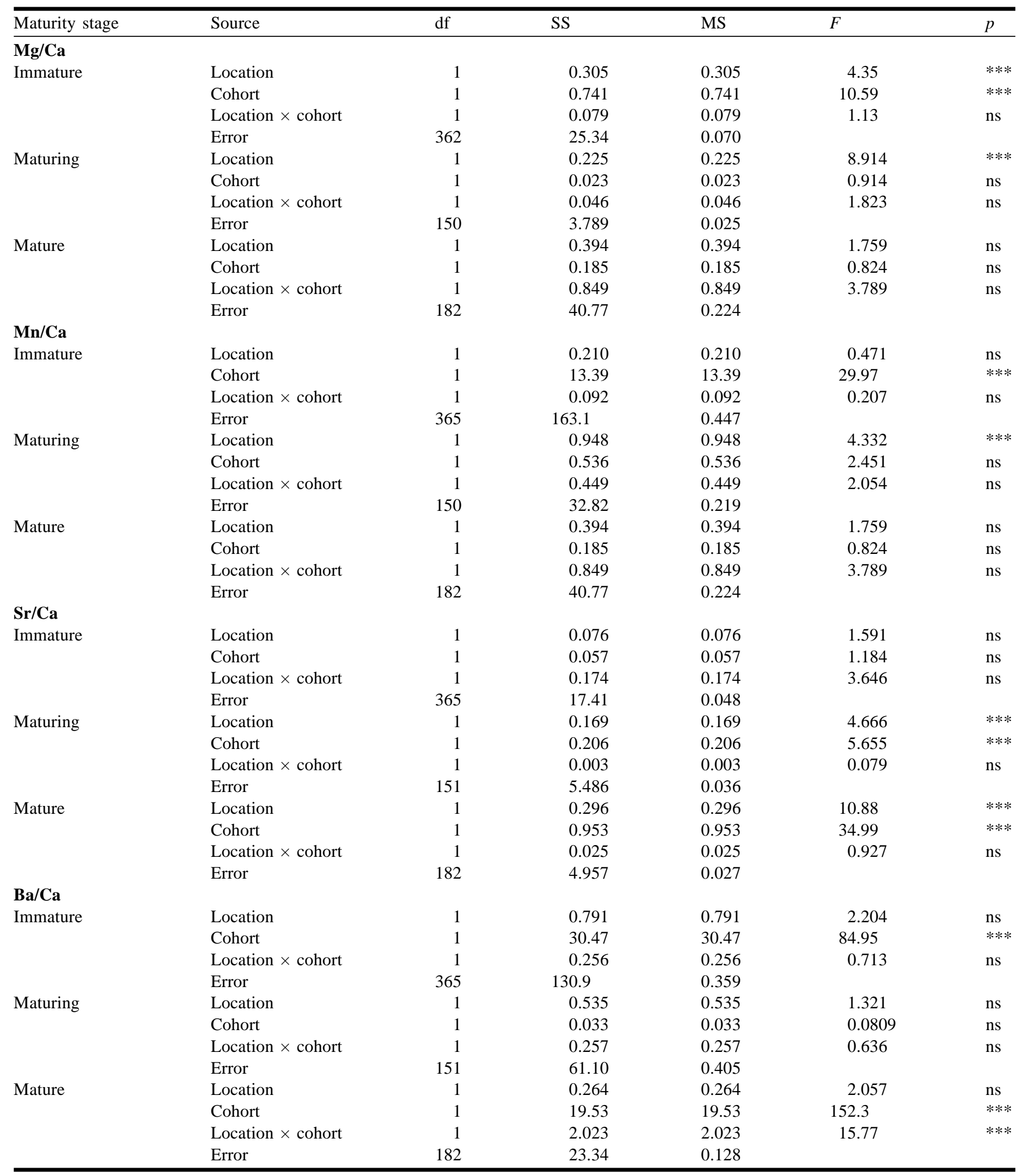

Note: SS, sum of squares; MS, mean squares; ***, $p$ significant at $\alpha=0.05$; ns, nonsignificant. 
lated with $\mathrm{Ca}^{2+}$ at different times of the day, and the high $\mathrm{Mg}$ concentration is associated with the deposition of organic component into the statolith. The proportion of organic component in statoliths decreases with the size of squid (Bettencourt and Guerra 2000), and concentrations of $\mathrm{Mg}$ would be expected to decrease correspondingly with maturity stage. Manganese followed a similar ontogenetic trend as $\mathrm{Mg}$ and therefore may also be differentially associated with the organic matrix of statoliths. An association with the organic content of the statolith may also explain why statoliths from the autumn-spawned cohort showed consistently higher $\mathrm{Mg} / \mathrm{Ca}$ and $\mathrm{Mn} / \mathrm{Ca}$ ratios than those from the springspawned cohort across all maturity stages. Given the long residence time of $\mathrm{Mg}$ in ocean waters, it is unlikely that squid at the different locations experienced varying concentrations of dissolved $\mathrm{Mg} 2+$. Mitsuguchi et al. (1996) reported that $\mathrm{Mg} / \mathrm{Ca}$ ratios were positively correlated with temperature in coral skeletons, but it seems unlikely that the autumn-spawned cohort was consistently exposed to higher temperatures than the spring-spawned cohort (Arkhipkin et al. 2004). However, differences in Mg and Mn content could be explained if organic content varied with growth rate and growth rate varied across cohorts.

Genetic studies using allozymes (Carvalho and Pitcher 1989) and microsatellite DNA (Shaw et al. 2004) have found that seasonal cohorts and geographic groupings of L. gahi around the Falkland Islands represent a single, genetically homogeneous population. However, the existence of spawning peaks (one in autumn and the other one in spring) is consistent among years (Agnew et al. 1998), as is the location of spawning grounds both to the north and to the south of the islands (Arkhipkin et al. 2000). The results of the present study revealed that spring- and autumn-spawned cohorts have specific elemental signatures in statoliths that are significantly different at every maturity stage. Moreover, there is significant geographic variation in the elemental composition of statoliths between the northern and southern regions of the species' range. These results are inconsistent with the premise that there is a single population that is well mixed across its geographic range at all maturity stages. Indeed, the spatial differences in elemental signatures can only be explained by concluding that the various groups of squid experienced different environments through a substantial portion of their lives and thus must have remained largely separate during that time. These results are most consistent with the view that the northern and southern spawning groups represent distinct population components with low-level intermixing of spawners sufficient to homogenize any genetic differences. However, given our use of dissolved statoliths, which provide an integrated elemental signature over an individual's lifetime, it is not possible to reject alternative explanations such as random mixing in the early life history followed by segregation between groups.

In light of the geographic differences in elemental signatures, as well as the geochemical and structural similarity between statoliths and otoliths, it appears likely that the elemental composition of statoliths reflects the environmental conditions experienced by individuals during their life. As such, an age-structured record of ecological events is stored in the daily growth sequence of the statolith microstructure.
The use of whole dissolved statoliths in our study did not allow us to disentangle the age-structured movements of the cohorts. Nonetheless, the results highlight the potential for elemental signatures in squid statoliths to provide information on population structure and connectivity. Further work utilizing laser ablation ICP-MS to probe specific areas of the statoliths (Thorrold and Shuttleworth 2000) may resolve stage-specific migrations and habitat use by L. gahi in shelf waters of the Falkland Islands. Alternatively, dissolved statoliths can be used to identify and track specific groups of squid as they mix with other groups over short periods of time (Campana et al. 1999). These types of results would be difficult, if not impossible, to obtain with traditional tagging techniques or population genetic markers.

\section{Acknowledgements}

The research was funded by the Falkland Islands Government and was also supported in part by National Science Foundation grants OCE-9871047 and OCE-0134998 to S.R.T. We thank Dr. Christopher Latkoczy for assistance with the ICP-MS analyses, Janna Chtcherbich for statolith preparation, and Linda Marks for technical assistance.

\section{References}

Agnew, D.J., Baranowski, R., Beddington, J.R., des Clers, S., and Nolan, C.P. 1998. Approaches to assessing stocks of Loligo gahi around the Falkland Islands. Fish. Res. 35: 155-169.

Arkhipkin, A.I. 1991. Methods for cephalopod age and growth studies with emphasis on statolith ageing techniques. In Squid age determination using statoliths. Edited by P. Jereb, S. Ragonese, and S. von Boletzky. N.T.R.-I.T.P.P. Special Publications, Mazara del Vallo, Italy. pp. 11-17.

Arkhipkin, A.I., Laptikhovsky, V.V., and Middleton, D.A.J. 2000. Adaptations for the cold water spawning in squid of the family Loliginidae: Loligo gahi around the Falkland Islands. J. Molluscan Stud. 66: 551-564.

Arkhipkin, A., Grzebielec, R., Sirota, A.M., Remeslo, A.V., Polishchuk, I.A., and Middleton, D.A.J. 2004. The influence of seasonal environmental changes on ontogenetic migrations of the squid Loligo gahi on the Falkland shelf. Fish. Oceanogr. 13: 1-9.

Beck, J.W., Edwards, R.L., Ito, E., Taylor, F.W., Recy, J., Rougerie, F., Joannot, P., and Henin, C. 1992. Sea-surface temperature from coral skeletal strontium/calcium ratios. Science (Wash., DC), 257: 644-647.

Bettencourt, V., and Guerra, A. 2000. Growth increments and biomineralization process in cephalopod statolith. J. Exp. Mar. Biol. Ecol. 248: 191-205.

Boyle, E.A. 1988. Cadmium: chemical tracer of deepwater paleoceanography. Paleoceanography, 3: 471-489.

Campana, S.E. 1999. Chemistry and composition of fish otoliths: pathways, mechanisms and applications. Mar. Ecol. Prog. Ser. 188: 263-297.

Campana, S.E., and Thorrold, S.R. 2001. Otoliths, increments and elements: keys to a comprehensive understanding of fish populations? Can. J. Fish. Aquat. Sci. 58: 30-38.

Campana, S.E., Chouinard, G.A., Hanson, J.M., and Fréchet, A. 1999. Mixing and migration of overwintering cod stocks near the mouth of the Gulf of St. Lawrence. Can. J. Fish. Aquat. Sci. 56: $1873-1881$. 
Carvalho, G.R., and Pitcher, T.J. 1989. Biochemical genetic studies on the Patagonian squid Loligo gahi d'Orbigny. II. Population structure in Falkland waters using isozymes, morphometrics and life history data. J. Exp. Mar. Biol. Ecol. 126: 243-258.

Clarke, M.R. 1978. The cephalopod statolith — an introduction to its form. J. Mar. Biol. Assoc. UK, 58: 701-712.

Donat, J.R., and Bruland, K.W. 1995. Trace elements in the oceans. In Trace elements in natural waters. Edited by B. Salbu and E. Steinnes. CRC Press, Boca Raton, Fla. pp. 247-281.

Hanlon, R.T., and Messenger, J.B. 1996. Cephalopod behaviour. Cambridge University Press, Cambridge, UK.

Hanlon, R.T., Bidwell, J.P., and Tait, R. 1989. Strontium is required for statolith development and thus normal swimming behavior of hatching cephalopods. J. Exp. Biol. 141: 187-195.

Hatfield, E.M.C., and Des Clers, S. 1998. Fisheries management and research for Loligo gahi in the Falkland Islands. Calif. Coop. Oceanic Fish. Invest. Rep. 39: 81-91.

Ikeda, Y., Arai, N., Sakamoto, W., Murayama, T., Maeda, K., and Yoshida, K. 1995. Preliminary report on the PIXE analysis of the squid statoliths. Int. J. PIXE, 5: 159-162.

Ikeda, Y., Arai, N., Sakamoto, W., Nateewathana, A., Murayama, T., Yatsu, A., and Yoshida, K. 1996. PIXE analysis of trace elements in squid statoliths: comparison between Ommastrephidae and Loliginidae. Int. J. PIXE, 6: 537-542.

Ikeda, Y., Arai, N., Sakamoto, W., Kidokoro, H., Yatsu, A., Nateewathana, A., and Yoshida, K. 1997. Comparison on trace elements in squid statoliths of different species' origin as available key for taxonomic and phylogenetic study. Int. J. PIXE, 7: 141-146.

Ikeda, Y., Arai, N., Sakamoto, W., Mitsuhashi, M., and Yoshida, K. 1999. Preliminary report on PIXE analysis for trace elements of Octopus dofleini statoliths. Fish. Sci. 65: 161-162.

Ikeda, Y., Yatsu, A., Arai, N., and Sakamoto, W. 2002. Concentration of statolith trace elements in the jumbo flying squid during El Niño and non-El Niño years in the eastern Pacific. J. Mar. Biol. Assoc. U.K., 82: 863-866.

Jackson, G.D. 1994. Application and future potential of statolith increment analysis in squids and sepioids. Can. J. Fish. Aquat. Sci. 51: 2612-2625.

Lea, D.W., Shen, G.T., and Boyle, E.A. 1989. Coralline barium records temporal variability in equatorial Pacific upwelling. Nature (Lond.), 340: 373-376.

Lipinski, M.R. 1979. Universal maturity scale for the commercially important squid (Cephalopoda: Teuthoidea). The results of maturity classifications of the Illex illecebrosus (LeSueur, 1821) populations for the years 1973-1977. ICNAF Res. Doc. 79/II/38.

Lipinski, M.R. 1986. Methods for the validation of squid age from statoliths. J. Mar. Biol. Assoc. UK, 66: 505-526.

Lipinski, M., Durholtz, M.D., and Underhill, L.G. 1998. Field validation of age readings from the statoliths of chokka squid Loligo vulgaris reynaudii d'Orbigny, 1845 and an assessment of associated errors. ICES J. Mar. Sci. 55: 240-259.

Mitsuguchi, T., Matsumoto, E., Abe, O., Uchida, T., and Isdale, P.J. 1996. $\mathrm{Mg} / \mathrm{Ca}$ thermometry in coral skeletons. Science (Wash., DC), 274: 961-963.

Morris, C.C. 1991. Statocyst fluid composition and its effects on calcium carbonate precipitation in the squid Alloteuthis subulata (Lamarck, 1798): towards a model for biomineralization. Bull. Mar. Sci. 49: 379-388.
Nigmatullin, Ch.M., Nesis, K.N., and Arkhipkin, A.I. 2001. Biology of the jumbo squid Dosidicus gigas (Cephalopoda: Ommastrephidae). Fish. Res. 54: 9-19.

Patterson, K.R. 1988. Life history of Patagonian squid Loligo gahi and growth parameter estimates using least square fits to linear and von Bertalanffy models. Mar. Ecol. Prog. Ser. 47: 65-74.

Radtke, R.L. 1983. Chemical and structural characteristics of statoliths from the short-finned squid Illex illecebrosus. Mar. Biol. 76: 47-54.

Rodhouse, P.G.K., Robinson, K., Gajdatsy, S.B., Daly, H.I., and Ashmore, M.J.S. 1994. Growth, age structure and environmental history in cephalopod Martialia hyadesi (Teuthoidea: Ommastrephidae) at the Antractic Polar Frontal Zone and on the Patagonian Shelf Edge. Antarct. Sci. 6: 259-268.

Rosenthal, Y., Field, P.M., and Sherrell, R.M. 1999. Precise determination of element/calcium ratios in calcareous samples using sector field inductively coupled plasma mass spectrometry. Anal. Chem. 71: 3248-3253.

Shaw, P.W., Arkhipkin, A.I., Adcock, G.J., Burnett, W.J., Carvalho, G.R., Scherbich, J.N., and Villegas, P.A. 2004. Ecological plasticity within the single interbreeding population of the Patagonian squid Loligo gahi in the Southwest Atlantic. Mar. Biol. 144: 961-970.

Swart, P.K., Elderfield, H., and Greaves, M.J. 2002. A high-resolution calibration of $\mathrm{Sr} / \mathrm{Ca}$ thermometry using the Caribbean coral Montastraea annularis. Geochem. Geophys. Geosyst. 3: 8402.

Thorrold, S.R., and Shuttleworth, S. 2000. In situ analysis of trace elements and isotope ratios in fish otoliths using laser ablation sector field inductively coupled plasma mass spectrometry. Can. J. Fish. Aquat. Sci. 57: 1232-1242.

Thorrold, S.R., Jones, G.P., Hellberg, M.E., Burton, R.S., Swearer, S.E., Niegel, J.E., Morgan, S.G., and Warner, R.R. 2002. Quantifying larval retention and connectivity in marine populations with artificial and natural markers. Bull. Mar. Sci. 70(Suppl. 1): 291-308.

Winer, B. 1971. Statistical principles in experimental design. 2nd ed. McGraw-Hill, New York.

Yatsu, A., Mochioka, N., Morishita, K., and Toh, H. 1998. Strontium/ calcium ratios in statoliths of the neon flying squid, Ommastrephes bartrami (Cephalopoda), in the North Pacific Ocean. Mar. Biol. 131: $275-282$.

Yoshinaga, J., Morita, M., and Edmonds, J.S. 1999. Determination of copper, zinc, cadmium and lead in a fish otolith certified reference material by isotope dilution inductively coupled plasma mass spectrometry using off-line solvent extraction. J. Anal. At. Spectrom. 14: 1589-1592.

Yoshinaga, J., Morita, M., and Edmonds, J.S. 2000. Fish otolith reference material for quality assurance of chemical analyses. Mar. Chem. 69: 91-97.

Zacherl, D.C., Manríquez, P.H., Paradis, G., Day, R.W., Castilla, J.C., Warner, R.R., Lea, D.W., and Gaines, S.D. 2003a. Trace elemental fingerprinting of gastropod statoliths to study larval dispersal trajectories. Mar. Ecol. Prog. Ser. 248: 297-303.

Zacherl, D.C., Paradis, G.D., and Lea, D.W. 2003b. Barium and strontium uptake into larval protoconchs and statoliths of the marine neogastropod Kelletia kelletii. Geochim. Cosmochim. Acta, 67: 4091-4099.

Zyrjanov, V.N., and Severov, D.N. 1979. Water circulation in the Falkland - Patagonian region and its seasonal variability. Okeanologiya, 29: 782-790. 